\title{
ІНТЕГРАЛЬНИЙ ПОКАЗНИК ЯКОСТІ ДОДИПЛОМНОЇ ПІДГОТОВКИ ЛІКАРІВ ДЛЯ НАДАННЯ ПЕРВИННОЇ МЕДИЧНОЇ ДОПОМОГИ ЯК РЕЗУЛЬТАТ РОЗВ'ЯЗКУ ЗАДАЧІ ПРИКЛАДНОГО СИСТЕМНОГО АНАЛІЗУ
}

\section{П. Р. Сельський}

\author{
ДВНЗ «Тернопільський державний медичний університет \\ імені І. Я. Горбачевського МОЗ України»
}

\begin{abstract}
В статті висвітлено досвід впровадження інноваційних оцінювальних методик у Тернопільському державному медичному університеті імені І. Я. Горбачевського. Запропоновано методику порівняльного аналізу якості додипломної підготовки лікарів у різних групах дослідження. Для розробки інтегрального показника якості підготовки фрахівців для роботи на первинному рівні надання медичної допомоги використано метод аналізу ієрархій Сааті як результат розв'язку задачі прикладного системного аналізу. Зазначений показник може бути застосований щодо окремого студента, курсу, фракультету, університету чи галузі в цілому.
\end{abstract}

Ключові слова: інноваційні оцінювальні методики, метод аналізу ієрархій Сааті, інтегральний показник якості додипломної підготовки лікарів.

\section{ИНТЕГРАЛЬНЫЙ ПОКАЗАТЕЛЬ КАЧЕСТВА ДОДИПЛОМНОЙ ПОДГОТОВКИ ВРАЧЕЙ ДЛЯ ОКАЗАНИЯ ПЕРВИЧНОЙ МЕДИЦИНСКОЙ ПОМОЩИ КАК РЕЗУЛЬТАТ РЕШЕНИЯ ЗАДАЧИ ПРИКЛАДНОГО СИСТЕМНОГО АНАЛИЗА}

\section{П. Р. Сельський}

ГВУЗ «Тернопольский государственный медицинский университет имени И. Я. Горбачевского МЗ Украины»

\begin{abstract}
В статье рассмотрен опыт внедрения инновационных оценочных методик в Тернопольском государственном медицинском университете имени И. Я. Горбачевского. Предложена методика сравнительного анализа качества додипломной подготовки врачей в разных группах исследования. Для разработки интегрального показателя качества подготовки специалистов для работы на первичном уровне оказания медицинской помощи использован метод анализа иерархий Саати как результат решения задачи прикладного системного анализа. Указанный показатель может быть применен в отношении отдельного студента, курса, факультета, университета или отрасли в целом.

Ключевые слова: инновационные методики оценивания, метод анализа иерархий Саати, интегральный показатель качества додипломной подготовки врачей

\section{INTEGRAL DESCRIPTOR OF THE PRE-GRADUATE TRAINING OF MEDICAL DOCTORS FOR THE PROVIDING OF THE FIRST AID AS A RESULT OF PROBLEM SOLUTION ON APPLIED SYSTEM ANALYSIS}

P. R. Selskyy

\author{
SHEI «Ternopil State Medical University by I. Ya. Horbachevsky of MPH of Ukraine»
}

\begin{abstract}
The article describes an implementation experience of the innovative assessment methods at the I. Ya. Horbachevsky Ternopil State Medical University. The method of comparative analysis of the quality of the pre-graduation training of medical doctors in different investigational groups is proposed. In order to develop the integral descriptor of the training quality of the medical professionals for the job at the primary level of healthcare and medical treatment, the Saati method of hierarchies analysis was used as a result of the problem solution on the applied system analysis. The developed descriptor can be used for individual student, entire course, faculty, university, or for the corresponding entity as a whole.
\end{abstract}

Kew words: innovational evaluative methods, Saati method of hierarchies analysis, integral descriptor of quality of pregraduation training of medical doctors.

(ㄷ П. Р. Сельський 
Вступ. Одним із головних напрямів підвищення якості підготовки майбутніх лікарів $\epsilon$ впровадження інформаційних, комунікаційних i комп'ютерних технологій, що дає змогу реалізації новітніх методів організації навчального процесу у медичній освіті [1-3]. В освітніх установах усе більш масового характеру набуває впровадження систем дистанційного навчання [4, 5]. Застосування новітніх технологій вимагає нового підходу й до систем оцінювання якості підготовки майбутніх лікарів [6, 7]. Особливо це актуально при підготовці фахівців для надання первинної медико-санітарної допомоги, зважаючи на низький відсоток (69,2%) укомплектованості лікарями селищних лікарських амбулаторій.

Процедура та методика оцінювання, як одного із завершальних етапів діяльності студента, суттєво впливають на остаточні результати, можливість аналізу та статистичну достовірність оцінок. Проте навіть при застосуванні стандартизованих методів, в першу чергу тестування, проблематично здійснити порівняльний аналіз якості підготовки у різних групах дослідження (на рівні курсу, факультету, університету, галузі), зважаючи на такі чинники як рівні компетентності на попередніх етапах, контингент студентів, умови навчання та інше.

Мета дослідження. Розробити інтегральний показник якості додипломної підготовки лікаря для роботи на первинному рівні на основі алгоритму прикладного системного аналізу.

Матеріали та методи. Для аналізу ефективності впровадження новітніх інформаційних технологій та рівня якості підготовки фахівців у Тернопільському державному медичному університеті імені І. Я. Горбачевського (ТДМУ) проведено констатувальний етап дослідження шляхом аналізу поточної та підсумкової успішності (табл. 1) студентів-медиків 1-5 курсів та випускного 6 курсу за 2011/2012 навчальний рік (н.p.). Аналіз здійснювали за курсами та потоками. 3 метою порівняльного аналізу вивчили показники успішності за 2010/2011 н.р. Для контрольного оцінювання взято успішність студентів за результатами традиційного усного оцінювання знань. У якості групи контролю досліджено успішність студентів на іспитах за традиційною методикою за минулі роки (2004/2005 н.p. - 2008/2009 н.р.). Для аналізу використано успішність за попередній рік перед впровадженням кредитно-модульної системи організації навчального процесу (КМСОНП) та комплексного семестрового тестового іспиту на курсі: середній бал поточної успішності (CE), середній бал за КСТІ - підсумковий модульний контроль (CК), результат оцінювання лінії практичних навичок (УЛ), оцінка, отримана на ОСКІ (УО).

При аналізі результатів тестування відмінності між середніми значеннями оцінювали за критерієм Стьюдента із використанням пакетів програм MS Excel (Microsoft Office 2003). Відмінності вважали достовірними при рівні $\mathrm{p}<0,05$.

Таблиця 1. Розподіл груп дослідження за курсами та потоками

\begin{tabular}{|c|c|c|}
\hline \multirow{2}{*}{ Курс } & \multicolumn{2}{|c|}{ Кількість студентів-медиків, чол. } \\
\cline { 2 - 3 } & група дослідження & $\begin{array}{c}\text { група } \\
\text { контролю }\end{array}$ \\
\hline 1 & 235 & 46 \\
\hline 2 & 341 & 45 \\
\hline 3 & 269 & 43 \\
\hline 4 & 201 & 44 \\
\hline 5 & 234 & 43 \\
\hline 6 & 237 & 40 \\
\hline Всього & 1748 & 261 \\
\hline
\end{tabular}

Алгоритм прикладного системного аналізу [8-10] використано при розробці концептуального представлення інформаційної моделі та 3 метою визначення інтегрального показника якості підготовки фахівців для роботи на первинному рівні надання медичної допомоги. Одним із підходів системного аналізу до вирішення проблем такого роду є метод аналізу ієрархій (MAI), запропонований американським математиком Томасом Сааті на початку 1990-х років [8].

MAI - це математичний інструмент системного підходу до складних проблем прийняття рішень. MAI не пропонує «правильне» рішення, а забезпечує в інтерактивному режимі знаходження такого варіанта (альтернативи), який якнайкраще узгоджується із розумінням суті проблеми і вимогами

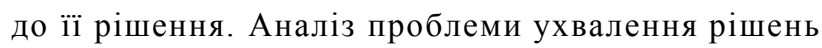
в MAI розпочинається 3 побудови ієрархічної структури, яка включає мету, критерії, альтернативи й інші дані та чинники, які впливають на вибір рішення. Ця структура відображає розуміння проблеми особою, яка приймає рішення. Кожен елемент ієрархії може представляти різні аспекти вирішуваної проблеми, причому до уваги можуть бути взяті як вимірювані кількісні параметри, так і якісні характеристики, об'єктивні дані і суб'єктивні експертні оцінки. Наступним етапом аналізу є ви- 
значення пріоритетів, які представляють відносну важливість або перевагу елементів побудованої ієрархічної структури, за допомогою процедури парних порівнянь. Особливістю MAI $\epsilon$ те, що безрозмірні пріоритети дозволяють обгрунтовано порівнювати неоднорідні чинники. На завершальному етапі аналізу виконується синтез (лінійна згортка) пріоритетів на ієрархії, в результаті чого обчислюються пріоритети альтернативних рішень відносно головної мети. Кращою вважається альтернатива $з$ максимальним значенням пріоритету. Процедура синтезу пріоритетів відбувається на основі суб'єктивних суджень експертів, число яких може вимірюватися десятками або сотнями. Найпростішим способом комп'ютерної підтримки є електронні таблиці [8].

Результати та обговорення. На основі методу системного аналізу здійснено декомпозицію проблеми управління якістю підготовки лікарів для роботи на первинному рівні надання медичної допомоги та показано підхід до визначення пріоритетності оцінювальних методик, що лежить в основі визначення інтегрального показника якості.

Формулювання проблеми в термінах методу аналізу ієрархій Сааті [206] виглядає наступним чином. Загальною метою досліджуваної проблеми $є$ якісне оцінювання теоретичних знань і практичних навичок студентів-медиків. На досягнення даної мети впливають такі сили: об'єктивність оцінювання на заняттях, об'єктивність дистанційного оцінювання «Moodle», організація роботи центру оцінювання практичних навичок, організація роботи ЦНТ, комплексна багаторівнева система захисту інформації. Дані сили визначаються такими акторами (дійовими особами): університетською адміністрацією, професорсько-викладацьким складом та безпосередньо самими студентами. Актори мають певні визначені цілі: оцінювання отримання студентами глибоких теоретичних знань та грунтовних навичок і вмінь, а також виявлення схильності до роботи в якості лікаря «Загальна практика - сімейна медицина», що особливо важливо, зважаючи на дефіцит висококваліфікованих фахівців на первинному рівні. Студенти бажають отримати об'єктивну оцінку своїх знань, навичок та вмінь. I насамкінець, $\epsilon$ кілька досліджуваних сценаріїв, таких як: поточна успішність, КСТІ, лінії практичних навичок та ОСКI.

Сценарії визначають ймовірність досягнення цілей, цілі впливають на акторів, актори скеровують сили, які остаточно визначають якість оцінювання студентів-медиків. Таким чином, $\epsilon$ можливість здійснити декомпозицію проблеми на п'яти рівнях ієрархії (рис. 2).

Рівень 1. Якісне оцінювання теоретичних знань i практичних навичок студентів-медиків (ЯО).

Рівень 2. Об'єктивність оцінювання на заняттях (3); об'єктивність дистанційного оцінювання «Moodle» (Д); організація роботи центру оцінювання практичних навичок (П); організація роботи ЦНТ (Ц); комплексна багаторівнева система захисту інформації (I).

Рівень 3. Університетська адміністрація (А); професорсько-викладацький склад (В); студенти (C).

Рівень 4. Оцінювання отримання студентами глибоких теоретичних знань (Т); оцінювання отримання студентами грунтовних навичок і вмінь $(\mathrm{H})$; виявлення схильності до роботи в якості лікаря спеціальності «Загальна практика - сімейна медицина» (М).

Рівень 5. Поточна успішність (У); КСТІ (К); лінії практичних навичок (Л); OCKI (O).

Відповідно до методу аналізу ієрархій будували матриці попарних порівнянь. Нехай задані довільні елементи А і В. У матрицях попарних порівнянь використовували такі числа:

- якщо А і В одинаково важливі, то заносимо 1;

- якщо А незначно важливіше від В, то заносимо 3 ;

- якщо А значно важливіше від В, то заносимо 5

- якщо А явно важливіше від В, то заносимо 7;

- якщо А абсолютно переважає В, то заносимо 9.

Числа 2, 4, 6, 8 і їх обернені величини використовували для полегшення компромісів між дещо відмінними від основних чисел судженнями.

Отже, відповідаючи на запитання типу «Наскільки важливішим $є$ вплив організації роботи ЦНТ, порівняно з об'єктивністю оцінювання на заняттях?» будувалась матриця попарних порівнянь на першому рівні:

$\begin{array}{cccccc} & 3 & \text { д } & \text { П } & \text { Ц } & \text { I } \\ 3 & 1 & 0,2 & 0,2 & 0,33 & 0,2 \\ \text { д } & 5 & 1 & 1 & 5 & 1 \\ \text { П } & 5 & 1 & 1 & 5 & 0,33 \\ \text { Ц } & 3 & 0,2 & 0,2 & 1 & 0,2 \\ \text { І } & 5 & 1 & 3 & 5 & 1\end{array}$

При цьому індекс узгодженості становить 0,07 , а вектор пріоритетів: 


$$
\begin{gathered}
0,0089 \\
0,53 \\
0,44 \\
0,14 \\
0,70
\end{gathered}
$$

Відповідаючи на запитання типу «Наскільки важливішим є вплив професорсько-викладацького складу, порівняно з адміністрацією університету, на об'єктивність оцінювання на заняттях?» будувалась матриця попарних порівнянь на другому рівні:

- для об'єктивності оцінювання на заняттях:

$\begin{array}{cccc} & \text { A } & \text { B } & \text { C } \\ \text { A } & 1 & 0,17 & 0,14 \\ \text { B } & 6 & 1 & 0,33 \\ \text { C } & 7 & 3 & 1\end{array}$

- для об'єктивності дистанційного оцінювання «Moodle»:

$\begin{array}{cccc} & \text { A } & \text { B } & \text { C } \\ \text { A } & 1 & 0,33 & 0,14 \\ \text { B } & 3 & 1 & 0,33 \\ \text { C } & 7 & 3 & 1\end{array}$

- для організації роботи центру оцінювання практичних навичок:

$\begin{array}{cccc} & \text { A } & \text { B } & \text { C } \\ \text { A } & 1 & 0,17 & 0,14 \\ \text { B } & 6 & 1 & 0,5 \\ \text { C } & 7 & 2 & 1\end{array}$

- щодо організації роботи ЦНТ:

$\begin{array}{cccc} & \text { A } & \text { B } & \text { C } \\ \text { A } & 1 & 0,14 & 0,11 \\ \text { B } & 7 & 1 & 0,33 \\ \text { C } & 9 & 3 & 1\end{array}$

- щодо комплексної багаторівневої системи захисту інформації:

$\begin{array}{cccc} & \text { A } & \text { B } & \text { C } \\ \text { A } & 1 & 0,11 & 0,11 \\ \text { B } & 9 & 1 & 1 \\ \text { C } & 9 & 1 & 1\end{array}$

При цьому матриця пріоритетів, яка складається 3 нормованих векторів, мала вигляд:

$\begin{array}{ccccc}0,094 & 0,12 & 0.10 & 0,076 & 0,078 \\ 0,41 & 0,34 & 0,51 & 0,40 & 0,70 \\ 0,91 & 0,93 & 0,85 & 0,91 & 0,70\end{array}$

Відповідаючи на запитання типу «Наскільки для адміністрації університету $є$ важливішим оцінювання отримання студентами грунтовних навиків та вмінь, порівняно з отриманням глибоких теоретичних знань?» будували матриці попарних порівнянь на третьому рівні:

- для адміністрації університету:

$\begin{array}{cccc} & \mathrm{T} & \mathrm{H} & \mathrm{M} \\ \mathrm{T} & \mathbf{1} & 0,33 & 0,2 \\ \mathrm{H} & 3 & \mathbf{1} & 0,5 \\ \mathrm{M} & 5 & 2 & \mathbf{1}\end{array}$

- для професорсько-викладацького складу:

$\begin{array}{cccc} & \mathrm{T} & \mathrm{H} & \mathrm{M} \\ \mathrm{T} & 1 & 1 & 5 \\ \mathrm{H} & 1 & 1 & 5 \\ \mathrm{M} & 0,2 & 0,2 & 1\end{array}$

- для студентів:

$\begin{array}{cccc} & \mathrm{T} & \mathrm{H} & \mathrm{M} \\ \mathrm{T} & 1 & 5 & 2 \\ \mathrm{H} & 0,2 & 1 & 0,33 \\ \mathrm{M} & 0,5 & 3 & 1\end{array}$

При цьому матриця пріоритетів мала вигляд:

$\begin{array}{lll}0,16 & 0,70 & 0,87 \\ 0,46 & 0,70 & 0,16 \\ 0,87 & 0,14 & 0,46\end{array}$

Відповідаючи на запитання типу «Наскільки для оцінювання отримання студентами глибоких теоретичних знань $\epsilon$ важливішою поточна успішність, порівняно із КСТІ?» приходили до матриць попарних порівнянь на четвертому рівні:

- 3 метою оцінювання отримання студентами глибоких теоретичних знань:

$\begin{array}{ccccc} & \text { У } & \text { К } & \text { Л } & \text { O } \\ \text { У } & 1 & 0,2 & 0,11 & 0,14 \\ \text { K } & 5 & 1 & 0,2 & 0,33 \\ \text { Л } & 9 & 5 & 1 & 2 \\ \text { O } & 7 & 3 & 0,5 & 1\end{array}$

- 3 метою оцінювання отримання студентами грунтовних навиків та вмінь:

$\begin{array}{ccccc} & \text { У } & \mathrm{K} & \text { Л } & \mathrm{O} \\ \mathrm{Y} & 1 & 0,5 & 9 & 7 \\ \mathrm{~K} & 2 & 1 & 5 & 3 \\ \text { Л } & 0,11 & 0,2 & 1 & 2 \\ \mathrm{O} & 0,14 & 0,33 & 0,5 & 1\end{array}$

- 3 метою виявлення схильності до роботи в якості лікаря за спеціальністю «Загальна практика - сімейна медицина»:

$\begin{array}{ccccc} & \text { У } & \text { K } & \text { Л } & \text { O } \\ \text { У } & 1 & 2 & 2 & 5 \\ \text { K } & 0,5 & 1 & 2 & 5 \\ \text { Л } & 0,5 & 0,5 & 1 & 2 \\ \text { О } & 0,2 & 0,2 & 0,5 & 1\end{array}$

При цьому матриця пріоритетів на четвертому рівні мала вигляд (в нормованому вигляді):

$\begin{array}{ccc}0,066 & 0,69 & 0,77 \\ 0,21 & 0,70 & 0,54 \\ 0,84 & 0,13 & 0,30 \\ 0,49 & 0,12 & 0,14\end{array}$




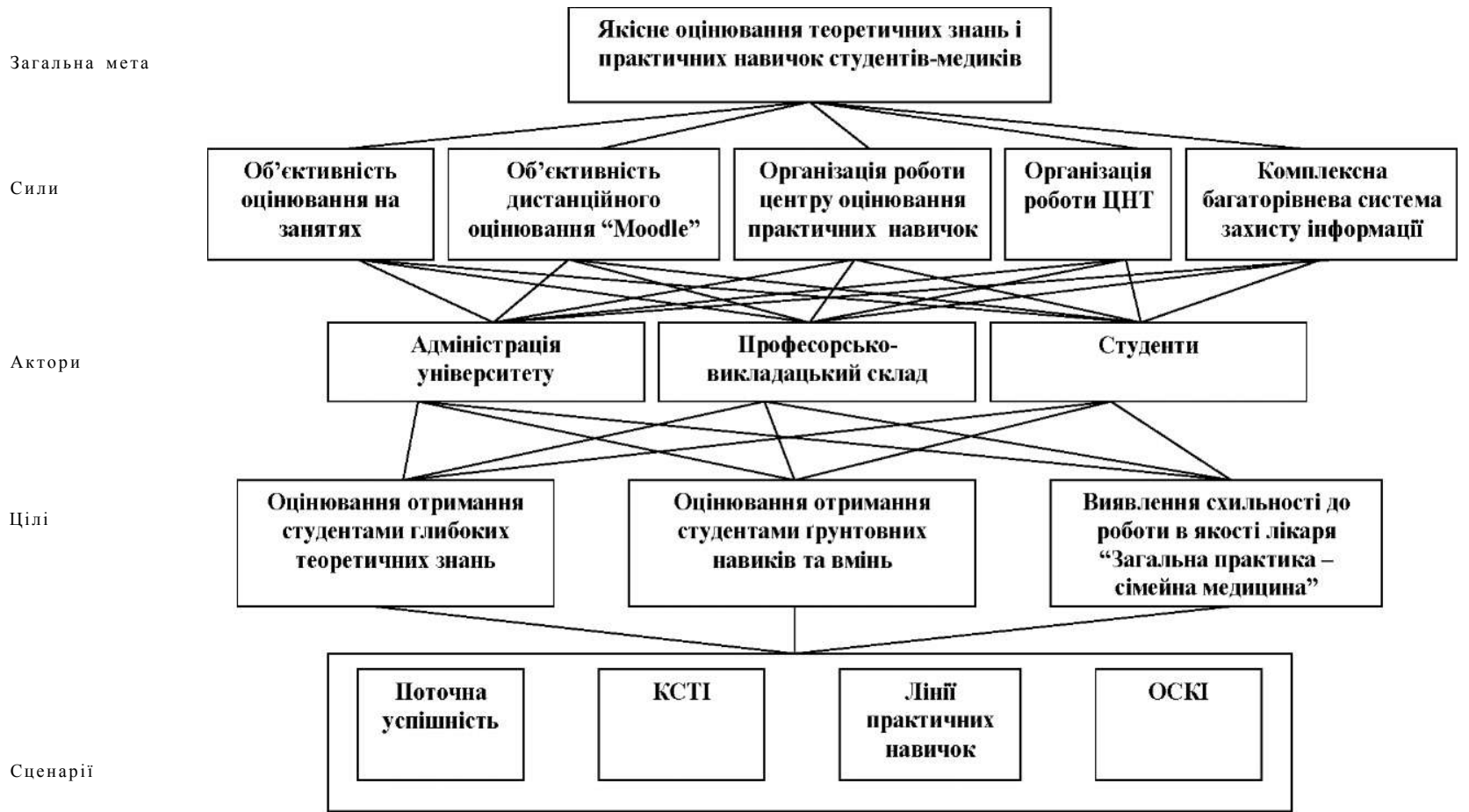

Puc. 2. Ієрархічна модель вирішення задачі якісного оцінювання професійно-практичної компетентності студентів-медиків.

Слід зазначити, що індекси узгодженості усіх матриць приймають значення, менше ніж 0,1 , що дозволяє застосувати процедуру методу аналізу ієрархій. Вектор пріоритетів завдання впливу розглянутих оцінювальних методик на якість підготовки фахівців для роботи на первинному рівні надання первинної медико-санітарної допомоги розраховувався як добуток попередньо отриманих матриць та векторів пріоритетів. Зазначений вектор становив:

$\begin{array}{ll}\mathrm{Y} & 0,18 \\ \mathrm{~K} & 0,17 \\ \text { Л } & 0,49 \\ \mathrm{O} & 0,16\end{array}$

3 урахуванням зазначеного вектора для визначення інтегрального показника якості (IП) підготовки фахівця для роботи на первинному рівні надання медичної допомоги (за рік навчання) пропонується така формула:

ІП=0,18 х СУ $+0,17 \times$ ×К $+0,49 \times$ УЛ $+0,16 \times$ УО, де СУ - середній бал поточної успішності, СК - середній бал за КСТІ (підсумковий модульний контроль), УЛ - результат оцінювання лінії практичних навичок, УО - оцінка, отримана на ОСКІ.

При цьому УЛ $=\left(\mathrm{E}_{\text {реальна }} / \mathrm{E}\right.$ максимальна $) x 12$, де $\mathrm{E}_{\text {реальна }}=\mathrm{E}_{\text {рівнї практичних навичок }}, \mathrm{E}_{\text {максимальна }}=5 \mathrm{n}$, де $\mathrm{n}=$ кількість практичних навичок у лінії.
IП використано може бути застосований щодо окремого студента, курсу, факультету чи університету в цілому.

Проведений аналіз ІП за результатами вивчення клінічних дисциплін на старших курсах виявив високий рівень зазначеного показника на четвертому (2010/2011 н.p. - 10,23 балів; 2011/2012 н.p. - 10,07 балів) та п'ятому курсах (2010/2011 н.p. - 10,08 балів; 2011/2012 н.p. - 10,34 балів). При цьому відмінність між ІП не перевищувала одного бала за 12-бальною шкалою.

Висновки. 1. На основі проведеного аналізу отримано такий порядок пріоритетів запроваджуваних інноваційних оцінювальних методик для підготовки лікаря за спеціальністю «Загальна практика - сімейна медицина»: принципово найважливішим виглядає впровадження ліній практичних навичок (49 \%); далі слідують методики оцінювання поточної успішності, включно з дистанційним тестуванням за СДТО «Moodle» (18\%), КСТІ (17\%) та ОСКІ (16\%).

2. Порядок пріоритетів суттєво визначається поставленими цілями, які можуть змінюватися залежно від якості надання медичної допомоги в країні, стану медичної освіти, потреби інтеграції у світовий освітній простір або ж орієнтації на національні традиції підготовки фахівців. 
Пріоритети в таких задачах можуть бути знайдені 3 використанням запропонованого в роботі підходу на основі методу аналізу ієрархій.

3. Метод аналізу ієрархій використано для розробки інтегрального показника якості підготовки фахівців для роботи на первинному рівні надання медичної допомоги, який використано як критерій обгрунтування керуючих впливів у моделі

\section{Література}

1. Аванесов В. С. Форма тестовых заданий : учебное пособие для учителей школ, лицеев, преподавателей вузов и колледжей. 2 изд., переработанное и расширенное / В. С. Аванесов. - М. : Центр тестирования, 2005. - $156 \mathrm{c}$

2. Анастази А. Психологическое тестирование / А. Анастази, С. Урбина. - СПб. : Питер, 2007. - 688 с.

3. Schuwirth L. W. Different written assessment methods : what can be said about their strengths and weaknesses? / L. W. Schuwirth, C. P. van der Vleuten // Med. Educ. - 2004 - № 38. - Р. 974-983.

4. Глибовець М. М. Деякі концепції реалізації навчальних взаємодій у системах дистанційної освіти / М. М. Глибовець, А. М. Глибовець, Ю. В. Рощенко // Вісник Київського університету. Серія : Фізикоматематичні науки. - 2010. - Випуск № 1. - С. 84-93.

5. Мінцер О. П. Концептуальні узагальнення щодо структурної організації комп'ютерних мереж вищих медичних навчальних закладів / О. П. Мінцер, О. А. Рижов, В. П. Марценюк // Медична інформатика та інженерія. - 2013. - № 4. - С. 7-15. управління якістю в медичній освіті та може бути застосований щодо окремого студента, курсу, факультету чи університету в цілому.

4. Виявлявся високий рівень інтегрального показника якості підготовки фахівців на четвертому (2010/2011 н.p. - 10,23 балів; 2011/2012 н.p. - 10,07 балів) та п'ятому курсах (2010/2011 н.p. - 10,08 балів; 2011/2012 н.p. - 10,34 балів).

6. Раковський Х. В. Інформаційні системи та технології у вищій школі: короткий курс, адаптований до технологій навчання [Текст] : навч. посібник / Х. В. Раковський, К. О. Метешкін. - Х. : ХУПС, 2009. - 152 с.

7. Сельський П. Р. Інформаційна система оцінювання знань в медичній освіті : монографія / П. Р. Сельський. - Тернопіль : ТДМУ 2013. - 212 с.

8. Саати Т. Принятие решений. Метод анализа иерархий / Т. Саати; [пер. с англ. Р. Г. Вачнадзе]. - М. : Радио и связь, 1993. - 278 с.

9. Марценюк В. П. Метод аналізу ієрархій в проблемі оцінювання знань в медичній освіті / В. П. Марценюк, А. В. Семенець // International Workshop «Problems of Decision Making under Uncertainties (PDMU-2009)», October 5-9, 2009, Abstracts. - Kamyanets-Podilsky, 2009. - P. 80-81.

10. Марценюк В. П. Медична інформатика. Методи системного аналізу : навч. посібник для ВНЗ / В. П. Марценюк, Н. О. Кравець ; Терноп. держ. мед. акад. ім. I. Я. Горбачевського. - Тернопіль : Укрмедкнига, 2002. - $176 \mathrm{c}$. 